\title{
UMBATRA
}

Indonesian Journal of Anthropology

Volume 4 (2) Desember 2019 || eISSN 2528-1569

pISSN 2528-2115 || http://jurnal.unpad.ac.id/umbara

DOI : 10.24198/umbara.v4i2.21697

\section{Hibridisasi Masyarakat Tionghoa di Kecamatan Lasem Pasca-Reformasi}

\author{
Mochamad Iqbal Jatmiko \\ Departemen Sosiologi, Fakultas Ilmu Sosial dan Ilmu Politik Universitas Gadjah Mada \\ mochamad.iqbal.j@mail.ugm.ac.id
}

\begin{abstract}
Chinese descendants in Indonesia, known as Tionghoa, have suffered from discrimination since the New Order regime, ranging from policy to identity status. The discrimination reached its peak in May 1998 as the riots blew up against Chinese descendants. The riots have been a footage of dark history that destroyed the identity of Chinese descendants in Indonesia leads and this leads to transformation in the social life of the Chinese descendants in Indonesia up to present, in particular in their identity. This research discusses the transformation of identity among Chinese descendants in Indonesia drawing on the case of Chinese descendants in Lasem. This research applies qualitative method with a case study approach. This research finds that the Chinese descendants in Lasem attempts to construct their new identity through culture hybridization and mimicry that is mingled with the identity of the local community. Through this process, they successfully create a new identity as Chinese-Javanese or wong Lasem that leads them to experience a survival and harmonious life with the local. Since the reforms, this new identity fosters the strong and harmonious interaction between the Javanese and Chinese in Lasem that slowly blurs the identity of the two ethnics.
\end{abstract}

Keywords: Chinese community, hybridization, social change

\begin{abstract}
Abstrak
Keturunan Cina di Indonesia, dikenal sebagai Tionghoa, telah menderita diskriminasi sejak rezim Orde Baru, mulai dari kebijakan hingga status identitas. Diskriminasi mencapai puncaknya pada Mei 1998 ketika kerusuhan meletus terhadap Tionghoa. Kerusuhan telah menjadi rekaman sejarah kelam yang menghancurkan identitas Tionghoa di Indonesia dan mengarah pada transformasi dalam kehidupan sosial keturunan Cina di Indonesia hingga saat ini, khususnya dalam identitas mereka. Penelitian ini membahas transformasi identitas keturunan Tionghoa di Indonesia berdasarkan kasus keturunan Tionghoa di Lasem. Penelitian ini menggunakan metode kualitatif dengan pendekatan studi kasus. Penelitian ini menemukan bahwa keturunan Tionghoa di Lasem berupaya membangun identitas baru mereka melalui hibridisasi budaya dan mimikri yang dicampur dengan identitas masyarakat setempat. Melalui proses ini, mereka berhasil menciptakan identitas baru sebagai orang Cina-Jawa atau wong Lasem yang menuntun kelangsungan hidup mereka dan hidup harmonis bersama masyarakat setempat. Sejak reformasi, identi-
\end{abstract}


tas baru ini menumbuhkan interaksi yang kuat dan harmonis antara orang Jawa dan Cina di Lasem yang perlahan-lahan mengaburkan identitas kedua etnis tersebut.

Kata kunci : masyarakat Tionghoa, hibridisasi, perubahan sosial

\section{Pendahuluan}

Memori kelam sejarah orang Tionghoa di Indonesia terjadi 21 tahun lalu, tepatnya pada Mei 1998. Pada tanggal itu, insiden tragis menghancurkan kehidupan orang Tionghoa di Jakarta yang menandai pecahnya konflik antar-etnis. Kasus kerusuhan etnis pada saat itu tidak hanya terpusat di Jakarta saja, melainkan juga terjadi di beberapa wilayah lain seperti Surabaya, Medan, Solo, dan Palembang. Orang Tionghoa kehilangan rumah dan bisnisnya. Mereka juga diburu sebagai objek sasaran kekerasan. Kasus pemerkosaan pada perempuan Tionghoa dan pembunuhan sadis semakin memperburuk situasi (Siegel, 1998).

Selama dua hari kerusuhan yaitu pada 13-15 Mei 1998, korban orang Tionghoa berjatuhan. Hingga kini, tidak ada data statistik yang valid mengenai jumlah korban. Tabel 1. adalah data jumlah korban tragedi Mei 1998 yang dirilis oleh Komnas Perempuan (2012) yang dihimpun dari pelbagai sumber lapangan.

\begin{tabular}{cccc}
\hline Lembaga & Meninggal & Luka & Jumlah \\
\hline $\begin{array}{c}\text { Tim Gabungan } \\
\text { Pencari Fakta }\end{array}$ & 1.217 & 91 & 1.308 \\
\hline $\begin{array}{c}\text { Polda Metro } \\
\text { Jaya }\end{array}$ & 451 & - & 451 \\
\hline $\begin{array}{c}\text { Komando } \\
\text { Daerah Militer }\end{array}$ & 463 & 69 & 532 \\
\hline $\begin{array}{c}\text { Pemda DKI } \\
\text { Jakarta }\end{array}$ & 288 & 101 & 389 \\
\hline
\end{tabular}

Tabel 1. Jumlah Korban Tragedi Mei 1998

Fakta lain menyebutkan bahwa lebih dari 1000 orang Tionghoa terbunuh. Sejumlah 4083 toko, properti, dan 40 pusat perbelanjaan milik orang Tionghoa dijarah dan dibakar. Begitu pun dengan tingginya kasus pemerkosaan terhadap wanita Tionghoa yang mencapai 168 orang (Wibowo, 2001). Meskipun demikian, masih terdapat selisih jumlah dengan data Komnas Perempuan (2012) yang memperlihatkan sebanyak 85 tindak kekerasan seksual terhadap perempuan Tionghoa, terdiri dari 52 perkosaan gang rape, 14 perkosaan dan kekerasan, 10 penganiayaan, dan 9 pelecehan seksual.

Pasca kerusuhan, situasi politik Indonesia berubah drastis. Era reformasi muncul, ditandai oleh mundurnya Soeharto, presiden yang telah menjabat selama 32 tahun, digantikan oleh wakilnya, B.J. Habibie. Salah satu agenda utama reformasi yakni pelaksanaan reformasi hukum. Presiden baru waktu itu menerbitkan surat Keputusan Presiden No. 26 tahun 1998 yang berisi penghentian istilah pribumi dan non-pribumi di seluruh kebijakan pemerintah, perencanaan program, dan implementasinya (Turner dan Allen, 2007). Langkah ini dilakukan presiden untuk menghilangkan dikotomi rasial pribumi dan non-pribumi yang dapat memicu anggapan bahwa semua warga keturunan non-Indonesia, termasuk Tionghoa, tetap dianggap sebagai warga asing meski lahir dan menetap di Indonesia dalam beberapa generasi. Konsekuensi anggapan non-pribumi, nantinya menyebabkan pembatasan terhadap pengakuan sebagai orang Indonesia keturunan; sehingga memunculkan stereotipe negatif sebagai orang asing dan dikategorikan non-pribumi karena berasal dari luar Indonesia, terutama bagi orang Tionghoa yang sekalipun telah memperoleh kewarganegaraan Indonesia (Hoon, 2006b).

Pada masa kepemimpinan Presiden Abdurrahman Wahid, Cina menjadi tujuan perjalanan 
kenegaraan pertamanya ke luar negeri. Pencabutan kebijakan larangan tahun 1978 tentang barang produksi Cina menjadi titik baru hubungan Indonesia-Cina setelah rezim Suharto. Sejak itu, relasi politik Indonesia-Cina pun semakin membaik secara signifikan (Sukma, 2009). Perbaikan relasi juga disokong dengan pelegalan beberapa terbitan cetak berbahasa Mandarin dan pengakuan identitas Tionghoa Indonesia. Fenomena ini menunjukkan bahwa era pasca-Soeharto telah menjadi periode yang menarik bagi kasus etnisitas Tionghoa. Mereka diperkenankan kembali membentuk dan mengekspresikan identitasnya yang pernah hilang selama lebih dari tiga dekade (Hoon, 2006a).

Momentum kerusuhan Mei 1998 di beberapa kota-kota besar menjadi titik tolak orang Tionghoa untuk meredefinisikan identitas dan kelangsungan hidupnya di era pasca-Soeharto. Hal ini seperti halnya yang terjadi di Kecamatan Lasem, Kabupaten Rembang, Jawa Tengah. Di sana, banyak orang keturunan Tionghoa yang membaur dengan kehidupan setempat. Konteks wilayah yang mengandung nilai-nilai Jawa menyebabkan masyarakat Tionghoa mengadopsi penuh budaya Jawa. Seluruh ekspresi kultural dan tradisi asli Tionghoa ditangguhkan supaya terintegrasi menjadi masyarakat Jawa Lasem.

Melihat kondisi seperti ini, perspektif poskolonial dinilai tepat untuk menjabarkan kehidupan identitas keturunan Tionghoa di Lasem. Melalui hibridisasi, identitas dilihat dalam cara pandang yang berbeda dari umumnya, yakni di antara perspektif esensialisme dan non-esensialisme. Dengan kata lain, hibridisasi berusaha mengaburkan batas identitas sekaligus mengafirmasi batas identitas dalam pengertian yang cair. Ruang itulah yang nantinya memunculkan mimikri, sebuah kekuasaan yang mendisiplinkan dan gagal mendisiplinkan sehingga menghasilkan suatu identitas yang familiar, tetapi sepenuhnya baru (Darmawan, 2014).

Berdasarkan uraian sebelumnya, artikel ini akan menelusuri dan menjelaskan kehidupan masyarakat keturunan Tionghoa di Lasem meliputi status identitas Tionghoa di Lasem pasca-reformasi, dan strategi mereka menghadapi perubahan sosial. Pelacakan sosio-historis dan kultural digunakan untuk menggambarkan transformasi identitas kelompok peranakan Tionghoa di Lasem.

Artikel ini berbeda dengan hasil penelitian Darmawan (2014) yang mengangkat fenomena identitas hibrid dengan menekankan pada term ke-Cina-an, ke-Indonesia-an, dan ke-Kristenan. Artikel ini berfokus pada negosiasi identitas budaya dengan melihat bahwa hibridasi identitas Jawa dan Tionghoa yang seimbang tampaknya mampu membentuk harmonisasi sehingga tercipta percampuran dua unsur budaya, yakni budaya Jawa-Tionghoa dan identitas baru menjadi Cina-Jawa.

\section{Kajian Pustaka}

\section{Perubahan Sosial}

Konsep masyarakat sebagai sebuah komunitas yang terstruktur secara sosial-budaya selalu berkembang dan berubah, baik secara internal maupun eksternal. Kontribusi sifat dialektis yang dimiliki dalam suatu tatanan masyarakat selamanya menciptakan siklus dinamis terhadap kehidupan. Di dalam pandangan struktural fungsional, masyarakat sebagai kesatuan sistem sosial akan saling berinteraksi secara berkesinambungan dalam situasi sosial dan lingkungan fisik (Parsons, 1951). Kondisi demikian mampu menstimulasi dinamika proses perubahan sosial yang berkelanjutan menuju perbaikan dan keutuhan kehidupan masyarakat. Dengan kata lain, interaksi ditujukan semata-mata agar individu 
mampu resisten terhadap perubahan dalam suatu kelompok sosial.

Dinamika perubahan sosial tidak terjadi secara singkat, melainkan dalam rentang waktu yang cukup lama. Hal ini sejalan dengan keberadaan masyarakat Tionghoa yang sudah lama bermukim di sekitaran wilayah Lasem. Kehidupan bersama dalam pluralisme membentuk keterikatan interaksi sosial yang kuat sehingga memungkinkan terjadinya perubahan sosial. Hal tersebut disebabkan oleh hubungan interaksi harmonis antara orang Tionghoa dengan penduduk asli Lasem yang mendorong transisi struktural melalui difusi sosial supaya dapat bertahan dalam kondisi seimbang. Pada umumnya, masyarakat Tionghoa sering mengulang dan mengubah tradisi yang dipinjam ke dalam beberapa cara sesuai dengan keuntungan yang dirasakan, seperti hubungan tanpa pembedaan golongan.

Transformasi masyarakat yang sedang berlangsung merekonstruksi ulang sub-struktur sosial baru yang bersifat plural. Sama halnya dengan perkembangan teori evolusi masyarakat modern - elaborasi pemikiran Weber, Durkheim, dan Spencer- yang melihat perubahan sosial dari proses diferensiasi struktural dan perkembangan masyarakat (Johnson, 1986). Parsons (1951) menjelaskan proses perkembangan yang dihubungkan dengan empat fungsi dasar. Pertama, adaptation, sebagai proses bertahan dan penyesuaian diri terhadap lingkungan sekitarnya. Tahap ini biasanya dimanfaatkan oleh individu dan/atau kelompok sosial untuk menyesuaikan diri ketika berada dalam konteks sosial dan wilayah yang berbeda. Internalisasi ataupun eksternalisasi nilai menjadi unsur lazim dalam proses adaptasi karena digunakan untuk menyesuaikan diri supaya dapat bertahan hidup dengan perubahan.

Kedua, goal attainment, merupakan kontestasi subjek untuk mencapai tujuan dan mem- pertahankan eksistensinya. Pada bagian ini, individu dan/atau kelompok dituntut memiliki sumber daya dan tujuan yang jelas untuk mencapai goal attainment. Apabila kedua aspek tersebut belum terpenuhi, maka proses sebelumnya menjadi tidak berguna.

Ketiga, integration, pengelolaan relasi antara adaptation, goal, dan latency secara sinergis untuk mengatur hubungan antar komponennya. Prosesnya dilihat sebagai tindakan yang memperbesar kesetiaan anggota pada kesatuan sistem sosial. Di dalam hal ini, terjadi prinsip pengorganisasian dengan memelihara solidaritas melalui pelibatan elemen untuk mengontrol, menjaga sub-sistem, dan mencegah gangguan dalam sistem.

Keempat, latent pattern maintenance yang digunakan dalam menjamin kelengkapan, pemeliharaan, dan menyempurnakan relasi ketika terjadi kesenjangan dalam sistem sosial lainnya. Artinya, sistem diwajibkan untuk mendistribusikan nilai-nilai bersama yang dimiliki sebagai bentuk kesadaran kolektif untuk pemeliharaan dan pengelolaan masalah yang terjadi.

\section{Dilema Identitas Tionghoa di Indonesia}

Keberadaan Tionghoa sebagai minoritas di Indonesia, sangat rentan terhadap diskriminasi Anti-Cina (Coppel, 2002; Coppel, 1994). Situasi sentimental masyarakat yang melihat masyarakat Tionghoa menimbulkan konsekuensi serius terhadap kehidupan individu, misalnya dalam ranah kehidupan sosial, ekonomi, budaya, dan politik (Poerwanto, 1976; Suryadinata, 1978).

Problematika identitas orang Tionghoa pertama kali muncul terkait dengan pilihan identitas kewarganegaraan setelah berlakunya Perjanjian Sino-Indonesia pada 22 April 1955. Pada Januari 1960 hingga Januari 1962, agenda nasionalisasi orang Cina di Indonesia 
sangat kuat dan intens. Hal ini terbukti dengan adanya pemilihan kewarganegaraan individu secara legal, yaitu menolak salah satu kewarganegaraannya supaya mendapatkan pengakuan tunggal atas status identitasnya (Tan dan Dahana, 1997).

Pada periode 1965-1966, orang Cina juga mengalami krisis identitas dengan adanya penutupan sekolah berbahasa Mandarin oleh pemerintah. Selain dicurigai berorientasi kepada komunis, mereka juga dituduh menyokong pendanaan PKI (Darmawan, 2014). Sebagai hasil dari kebijakan-kebijakan ini, terutama penutupan sekolah-sekolah bahasa Mandarin, orang Tionghoa di Indonesia terkekang untuk mengekspresikan tradisi budaya dan menjalankan adat istiadatnya.

Dilema identitas masyarakat Tionghoa mencapai puncaknya sejak penerapan kebijakan asimilasi yang diatur dalam instruksi presidium kabinet No.37/U/IN/6/1967 tentang Kebijaksanaan Pokok Penyelesaian Masalah Cina. Di dalam membentuk kebijakan nasional Indonesia selama Orde Baru (1966-1998), Presiden Soeharto menciptakan budaya baru dengan menegaskan kembali pentingnya ideologi Pancasila. Akan tetapi, implementasi kebijakan asimilasi yang dilakukan di masa Soeharto tersebut menyebabkan depolitisasi dan dekulturalisasi besar-besaran terhadap masyarakat Tionghoa sampai dengan terjadinya kerusuhan Mei 1998 (Darmawan, 2014; Hoon, 2006b).

\section{Hibridasi dan Mimikri}

Hibridasi dan mimikri pada dasarnya merupakan dua konsep kajian poskolonialisme yang berkorelasi karena keduanya merujuk pada perpaduan elemen kebudayaan. Hibridasi sering digunakan untuk mendeskripsikan interaksi antar-budaya yang berbeda sehingga menghasilkan budaya dan identitas baru dengan perwujudannya sendiri (Foulcher dan Day, 2008). Pembauran antara dua nilai budaya dan/atau identitas nan- tinya akan saling berinteraksi sehingga memproduksi kebaharuan entitasnya sendiri.

Berkaitan dengan hibridasi, nilai kebudayaan dan identitas dari kedua belah pihak harus ditangguhkan supaya mencapai konsensus nilai bersama. Keserasian nilai menjadi titik penting yang harus dilihat untuk mengurangi ketimpangan sosial pada saat interaksi dan negosiasi nilai budaya antar-kelompok. Hibridasi mencoba menjembatani dengan membentuk gagasan sinkretisme budaya yang melatarbelakangi kompleksitas keterikatan antar-budaya daripada distingsi kebudayaan yang diperkuat oleh paradigma multikulturalisme (Ang, 2001; Anthias, 2001; Hoon, 2006a, 2006b).

Akomodasi budaya dan masyarakat lokal melalui hibridasi menjadi cara untuk mendekonstruksi dikotomi antara "kami dan mereka". Prosesi silang budaya tidak hanya mengarahkan perhatian pada produk paduan budaya, melainkan penempatan posisi produk dalam ruang sosial-historis di bawah pemaksaan dan penolakan pada kekuasaan (Foulcher dan Day, 2008). Artinya, hasil hibridasi budaya — baik materiil atau immaterial - harus merepresentasikan dua unsur kebudayaan yang dapat diterima oleh masyarakat. Apresiasi terhadap identitas hibrida semacam itu dapat mendekonstruksi garis kaku relasi antagonistik antara Tionghoa dan non-Tionghoa, pribumi dan non-pribumi. Rincian dikotomi ini akan membantu melunakkan perbedaan mendasar yang terkait dengan identitas Tionghoa dan identitas pribumi. Artinya, hibridasi yang terjadi dalam masyarakat Tionghoa di Lasem secara signifikan dapat menghapus batas diskriminasi antar-etnis di Lasem.

Proses percampuran, pemaknaan, dan negosiasi budaya antar-masyarakat Tionghoa dan Jawa di Indonesia akan terus menerus dan sering berbelit-belit; bahkan tidak pernah mapan. Pengadopsian bentuk-bentuk kebudayaan seperti pakaian, makanan, dan sebagainya ber- 
jalan dinamis. Hal ini sejalan dengan pendapat Bhabha (1994) bahwa terdapat ruang liminal yang menjadi ranah negosiasi di antara dimensi ruang dengan yang lain. Predikat sebagai seorang migran, kelompok Tionghoa sudah semestinya terus mengalami berbagai percampuran budaya ataupun identitas sesuai dengan kondisi tempat hidupnya.

Unsur-unsur yang berbaur nantinya dapat diterjemahkan secara bahasa maupun budaya. Di dalam upaya melihat percampuran tersebut, Bhabha (1994) membagi ranah hibridasi menjadi empat bagian utama; pertama, rasial yang disebabkan oleh adanya fenomena biologis, sosial, dan perpindahan manusia sehingga memungkinkan terjadinya percampuran ras. Kedua, linguistik sebagai bentuk pertukaran ideologi bahasa karena adanya penjajahan di masa lampau; difasilitasi pendidikan. Ketiga, literatur yang dipahami sebagai narasi cerita, informasi, dan gaya penulisan penguasa yang nantinya disadur sehingga menginisiasi pribumi untuk menciptakan narasi sosial, politik, dan budayanya sendiri. Keempat, budaya yang merujuk pada hubungan entitas lokal dengan luar sehingga terjadi peniruan budaya.

Resonansi hibridasi akhirnya memicu timbulnya fenomena mimikri karena dalam percampuran budaya terdapat unsur peminjaman, peniruan, dan penyamaran berbagai elemen kebudayaan. Di dalam hal ini, fenomena mimikri mengaburkan ketertindasan dengan mengubah relasi sosial menjadi emulasi yang menenangkan dan terkungkung dalam ambivalensi menjadi identitas yang lain. Mimikri akan terus mengindikasikan makna yang sifatnya imitasi sekaligus subversi (Bhabha, 1994). Mimikri digunakan sebagai wahana dasar dalam sebuah identitas hibrida. Melalui mimikri, individu mencoba menyamarkan identitas, tradisi tradisional, dan sifat lain yang otentik dengan mengadaptasi identitas, perilaku, dan budaya dominan di sekitarnya.

\section{Metode}

Penelitian ini menggunakan metode kualitatif dengan pendekatan studi kasus yang bertujuan untuk mengetahui pola dinamika kehidupan masyarakat Tionghoa di Lasem. Penelitian dilakukan \pm selama lima minggu, yakni pada bulan Januari hingga Februari 2019. Lokasi penelitian dilakukan di Kabupaten Rembang dengan mengambil dua wilayah desa di Kecamatan Lasem, yakni Desa Karangturi dan Desa Babagan. Pemilihan dilandaskan pada beberapa aspek, yakni keterkaitan erat dengan kehidupan masyarakat Tionghoa serta keduanya identik sebagai sentra produksi batik tulis Lasem sejak tahun 1850 .

Teknik purposive digunakan untuk memilih informan penelitian, yaitu masyarakat keturunan Tionghoa yang lama menetap di Lasem, sedangkan teknik snowball untuk memperluas dan memudahkan pencarian informan selanjutnya. Teknik pengambilan data dilakukan dengan wawancara mendalam dan observasi langsung yang diharapkan dapat menghimpun data yang sistematis. Salah satu bentuk upaya mengantisipasi adanya bias penelitian dilakukan dengan menetapkan dasar pemikiran dalam strategi pengumpulan informasi dan menetapkan batas tertentu dari suatu kasus — waktu, peristiwa, dan proses.

\section{Hasil dan Pembahasan}

\section{Kehidupan Masyarakat Tionghoa di Lasem}

Menjelang masa pasca-orde baru hingga sekarang masyarakat Tionghoa di Indonesia tidak pernah menjadi kelompok yang homogen. Pluralisme yang bersifat kontekstual dan berdasarkan kelas sosial menjadi unit klasifikasi atas heterogenitas kehidupan masyarakat Tionghoa. Pada umumnya, klasifikasi kelompok keturunan tersebut dilandaskan secara berbeda dalam periode, wilayah, perkawinan, 
dan tempat kelahiran. Pertama, dilabeli sebagai totok yaitu pendatang kelahiran Cina dan/atau keturunan bukan campuran yang keluarganya telah berada di Indonesia selama dua sampai tiga generasi

Mereka memiliki pendidikan bahasa Mandarin dan orientasi budaya Cina, terutama ditunjukkan oleh penggunaan bahasa Mandarin. Kriteria tersebut membuat sulitnya mencari seorang totok di Indonesia, termasuk di wilayah Lasem. Masyarakat Tionghoa di Desa Karangturi dan Babagan juga meyakini bahwa figur yang dianggap totok sudah tidak ada.

"totok sudah susah sekarang, mungkin tidak ada di Lasem [...] sekarang jangan tanya ada berapa Tionghoa di Lasem, populasi orang keturunan di Lasem itu utuh gak? sudah jarang, contohnya gak usah banyak-banyak, gang empat kecil itu, berapa penghuninya? mungkin gak ada sepuluh cuma tinggal sepuh-sepuh" (Wawancara dengan SH, 2019)

Masyarakat Tionghoa di Lasem yang masih murni totok saat ini sudah hilang keberadaannya. Selain sulitnya melacak orang Tionghoa yang berstatus totok, banyak di antara keturunan awal golongan Tionghoa yang sudah meninggal dunia. Sisa-sisa yang tinggal di Lasem hanyalah peranakan Tionghoa, yaitu keturunan campuran antara Cina (biasanya laki-laki) dengan salah satu kelompok lokal di Indonesia (biasanya perempuan). Mayoritas keluarganya telah menetap di Indonesia setidaknya tiga generasi, berbicara bahasa Indonesia, dan orientasi budaya lebih kedaerahan (Coppel, 2002; Poerwanto, 1976; Tan dan Dahana, 1997).

Masyarakat peranakan Tionghoa yang tinggal di Lasem berjumlah banyak yang disebabkan oleh perkawinan silang. Pada umumnya, masyarakat Tionghoa menikah dengan warga setempat keturunan Jawa. Fenomena ini terjadi sekitar tahun 1990 sampai 2000an. Fenomena pernikahan silang ini akhirnya menyebabkan banyak peranakan dan semakin menyulitkan adanya seorang totok.

"orang Cina dulu banyak yang mbatik, terus mereka menikah dengan orang Jawa sini, di Lasem, kayak papa saya ini, papa saya itu Cina, tapi ibu saya Jawa anake wong mlarat (anaknya orang susah), ibu saya waktu itu janda, kerja buruh di batik milik Cino sini, papa saya sekarang [...] dulu istrinya papaku yang Cino nyuruh papa saya menikah dengan orang Jawa yang kere, ora brengsek (yang baik dan nurut), soalnya dulu gak punya anak, terus nikah karo ibuku yang janda, jadi saya ini termasuk blasteran, banyak kok orang Lasem yang blasteran seperti saya ini" (Wawancara dengan SR, 2019)

Tradisi pernikahan silang ini menjadi salah satu cara masyarakat Tionghoa yang hidup di Indonesia untuk berasimilasi. Walaupun orang Tionghoa melakukan adaptasi dengan lingkungan setempat, tetapi mereka masih tetap mempertahankan adat dan tradisi leluhurnya. Hal ini juga berlaku bagi masyarakat Tionghoa di Lasem yang sebagian besar sudah mengintegrasikan diri menjadi warga lokal; mayoritas Jawa. Meskipun memiliki ciri fisik sebagai keturunan Tionghoa, namun mereka beranggapan bahwa dirinya adalah masyarakat Jawa. Mereka tidak bertujuan untuk menghancurkan identitas aslinya sendiri, tetapi melakukan pengakuan atas kehidupan dirinya sebagai orang yang lahir dan besar di Jawa.

Represi anti-Cina yang berjalan selama Orde Baru tampaknya juga mengambil peran penting dalam degradasi ataupun penyembunyian identitas sebagai keturunan Tionghoa di Lasem. Para ahli mencatat bahwa terjadi kemerosotan penggunaan totok dan peranakan dalam mengidentifikasi orang Tionghoa; selaras dengan kasus di Lasem, ketika status keduanya susah untuk diketahui. 
Selain pelacakan asal-usul keturunan yang sulit, peristiwa pembantaian yang terjadi di Jakarta menyebabkan ketakutan beberapa masyarakat di Lasem untuk mengakui dirinya sebagai keturunan Tionghoa.

"sudah lama saya ganti nama, gara-gara Orde Baru dulu, sempat ribut soal identitas warga seperti saya ini [...] kan saya juga orang Lasem, makanya nama Jawa saya Purwati, banyak orang Cina di Lasem sini yang memiliki dua nama" (Wawancara dengan PW, 2019)

Hal tersebut disebabkan oleh program asimilasi paksa yang mengakibatkan peranakanisasi seluruh orang Tionghoa di Indonesia (Suryadinata, 1978). Masyarakat Tionghoa peranakan juga diwajibkan untuk berorientasi ke Indonesia; menggunakan bahasa Indonesia atau bahasa lokal di rumah, tidak berbicara bahasa Mandarin sama sekali, dan membatasi pengetahuan tentang tradisi Cina. Akibatnya, banyak penurunan jumlah nama marga di Lasem serta menutupi identitas aslinya sebagai seorang keturunan Tionghoa sehingga terkesan seolah-olah hilang.

"sekarang lihat, tahun setelah krismon, penurunan marga itu banyak dari Lasem, sempat dilarang sebelum ya sampai krismon, orang Tionghoa-nya itu juga mulai banyak menipis" (Wawancara dengan SH, 2019)

Cuplikan di atas menunjukkan bahwa rezim otoriter Soeharto membawa problematika kehidupan masyarakat Tionghoa selama di Indonesia sehingga harus bersembunyi di balik tabir identitas Jawa. Ketika pemerintahan Soeharto runtuh, masyarakat peranakan Tionghoa, termasuk di Lasem mulai sedikit mengungkap identitasnya walaupun belum sepenuhnya karena terdapat sisi traumatis. Selain itu, orang Tionghoa peranakan kemudian menghibridisasi budaya Tionghoa dan lokal dengan tujuan menyulitkan pelacakan ikatan historis dan tradisi autentiknya.

\section{Pluralisme Antar-golongan}

Lasem memiliki letak strategis di wilayah Pesisir Utara Jawa. Hal ini menjadikan Lasem sebagai jalur masuk perdagangan dan imigran dari berbagai daerah, termasuk dari Tiongkok. Keberagaman etnis dan budaya di Lasem berjalan secara harmonis. Banyaknya kelompok masyarakat Jawa dan Tionghoa juga tidak menghambat proses multikulturalisme karena saling melengkapi dan toleran (Atabik, 2016). Salah satu aspek dari proses hibridasi yang dialami oleh orang Tionghoa-Indonesia dicontohkan dalam penggunaan bahasa oleh orang Tionghoa peranakan yang telah tinggal di Indonesia selama berabad-abad. Peranakan cenderung menikah dengan penduduk setempat dan mengadopsi budaya setempat. Amalgamasi yang sejak lama terjadi semakin mempererat hubungan keduanya. Meskipun jumlah penduduk masyarakat Tionghoa sedikit, yakni sekitar 2\% dari total 49.502 jiwa, tidak menjadi alasan adanya diskriminasi dan perselisihan di Lasem.

Bentuk nyata akulturasi Jawa dengan Tionghoa yang paling tampak di dalam masyarakat Lasem adalah dialek dan penggunaan bahasa dalam aktivitas sehari-hari. Temporalitas orang Cina yang telah tinggal di Indonesia selama 600 hingga 1.000 tahun semakin memupuk asimilasi dengan penduduk setempat (Tzû-jan, Hsing, dan Hsi-Chih, 2016). Seperti pernyataan salah satu keturunan Tionghoa yang tinggal di Lasem yang sudah menggunakan Bahasa Jawa dan Indonesia ketika berkomunikasi.

"kalo aku sih gak bisa Bahasa Mandarin, keluargaku gak ada yang bisa, mereka semua termasuknya keturunan, agama saja kami beragama Kristen, udah gak ada Konghucu di keluarga kami, ngobrol 
juga pakai Bahasa Jawa dan Indonesia, mungkin keluarga kami sudah Nasionalis kali ya, di sekolah juga aku bicara pakai Bahasa Jawa dan Indonesia. Semua sama, gak ada yang beda." (Wawancara dengan SA, 2019)

Tidak ada perbedaan penggunaan bahasa antara masyarakat Tionghoa dan Etnis Jawa dalam berkomunikasi di masyarakat Lasem. Tan dan Dahana (1997) menyatakan bahwa orang Tionghoa sangat dipengaruhi oleh budaya kelompok etnis dominan di wilayahnya. Bahasa Jawa dengan logat Laseman menjadi tradisi dan kebiasaan masyarakat Tionghoa di Lasem. Bahasa Mandarin yang seharusnya menjadi bahasa induk kini tidak pernah dipelajari lagi sehingga mulai menghilang dalam tradisi keluarga.

Di wilayah lain, akulturasi budaya yang diekspresikan dalam penggunaan bahasa lokal atau campuran dari bahasa lokal dan bahasa Indonesia juga terjadi, misalnya Jawa di Jawa Tengah dan Jawa Timur, Sunda di Jawa Barat, Minangkabau di Sumatera Barat, Manado di Utara Sulawesi, Ambon di Maluku, dan Bali di Bali. Selain itu, adanya hibridasi linguistik bahasa Melayu-Hokkien yang diperkaya dengan Belanda dan bahasa barat lainnya semakin menjemukan kehidupan etnis di Indonesia (Hoon, 2006b, 2006a; Suryadinata, 1978; 2002).

Kepercayaan Konghucu pun mulai ditinggalkan dan digantikan menjadi Kristen, Katolik, dan Islam. Perubahan kehidupan orang Tionghoa dalam beberapa aspek tidak sampai mengubah hubungan antara masyarakat Tionghoa dan Lasem untuk tetap berjalan harmonis. Keharmonisan pluralisme golongan dituangkan dalam bentuk arsitektur bangunan tempat ibadah, seperti kelenteng, masjid, pondok pesantren dengan kubah bercorak Tionghoa, pos ronda, batik, dan kampung pecinan.

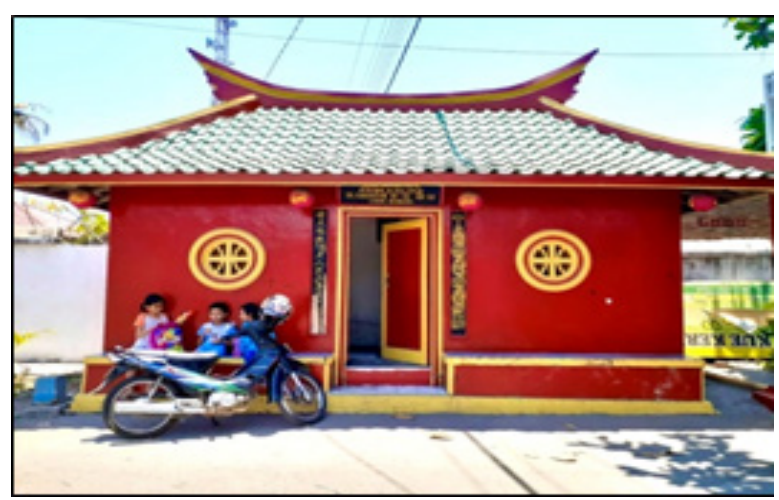

Gambar 1. Pos Ronda Hasil Akulturasi Budaya Jawa dan Tionghoa (Sumber: dokumentasi penulis)

Tingkat toleransi terjaga dengan baik melalui relasi antar masyarakat Lasem yang dapat dilihat dalam hal peringatan hari besar agama. Di Lasem, meskipun terdapat perbedaan kepercayaan beragama; 96\% dari jumlah penduduk Lasem beragama Islam termasuk masyarakat Tionghoa Lasem sebagian beragama Islam, tetapi tidak pernah ada kesenjangan maupun konflik berbasis SARA.

\begin{tabular}{lc}
\hline \multicolumn{1}{c}{ Agama } & Jumlah \\
\hline Islam & 47.423 \\
\hline Kristen Protestan & 1.045 \\
\hline Katolik & 762 \\
\hline Hindu & 22 \\
\hline Budha & 207 \\
\hline Kepercayaan lainnya & 43 \\
\hline \multicolumn{2}{c}{ Total } \\
\hline
\end{tabular}

Tabel 2. Data Pemeluk Agama Lasem (Sumber: Olahan Data BPS tahun 2018)

Berdasarkan tabel 2., agama Islam merupakan agama yang paling banyak dianut oleh masyarakat Lasem. Walaupun demikian, para ulama dan Kyai Lasem saling menghormati dan menghargai budaya Tionghoa di Lasem. Pembauran dan kebersamaan tampak nyata dari adanya Pondok Pesantren Kauman yang terletak di Desa Karangturi. Pondok Pesantren Kauman merupakan sebuah pondok keagamaan yang berada di wilayah masyarakat Tionghoa. Sebagian besar bangunan yang digunakan untuk aktivitas pondok memiliki corak arsitektur 
Tionghoa.

Selain itu, ritual keagamaan dan tradisi perayaan hari besar agama menjadi ciri khas yang menandai kebersamaan etnis di sana, sebab terdapat sinergitas untuk saling melengkapi; saat perayaan hari Imlek Cap Go Meh orang Jawa berperan sebagai pemain Barongsai dan menggotong patung-patung.

"di Lasem ini ada kelompok Tionghoa yang jaga Kelenteng, bahkan di toko Laut Bonang milik Om Rudi itu pekerjanya orang Jawa, setiap ada perayaan Imlek pemuda-pemuda Jawa yang bekerja di Laut Bonang itu bermain Barongsai, pokoknya sering kok terjadi pertukaran budaya di Lasem [...] pekerjanya kan banyak yang Islam, dia juga menyediakan tempat sembahyang buat karyawan" (Wawancara dengan YS, 2019)

Kebersamaan dalam pluralisme golongan di wilayah Lasem membentuk hubungan yang kondusif dan harmonis. Pembauran kedua golongan semakin memudarkan rasa primordialisme diskriminasi. Sekat-sekat kelas sosial antar-golongan juga tidak menunjukkan bukti yang relevan. Tindakan semacam itu yang memberikan kemudahan untuk saling menerima satu sama lain sehingga mendorong terjadinya hibridasi dan mimikri.

\section{Penangguhan Identitas Tionghoa}

Di bawah rezim Orde Baru, semua orang Tionghoa mengalami perampasan hak dan diskriminasi melalui dimensi militer dan politik. Banyak peranakan yang dipaksa pindah ke kota. Seluruh kartu identitas ditandai khusus dan adanya pembatasan akses hukum atas kegiatan komersial diperkenalkan. Penutupan dan nasionalisasi sekolah Tiongkok menjadi gencar dilakukan pemerintah; diikuti dengan pelarangan literatur, aktivitas budaya, dan tanda-tanda yang memiliki usur Tionghoa. Tekanan asimilasi yang diskriminatif membuat banyak orang Tionghoa-Indonesia me- nikahi pribumi, pindah agama ke Islam, dan mengadopsi nama-nama khas Indonesia (Carnegie, 2019; Tan dan Dahana, 1997).

Kota-kota di Provinsi Jawa Tengah, pada tahun 1990-an, rezim Orde Baru memberikan larangan pemutaran musik Mandarin pada perayaan malam Tahun Baru Lunar - dikenal sebagai Tahun Baru Imlek. Delik asimilasi minoritas dalam tubuh nasionalisme menjadi landasan utama dalam diskriminasi etnis pada waktu itu (Heryanto, 2015).

Pada tahun 1997-1998, kondisi semakin memperparah keberadaan masyarakat Tionghoa. Demonstrasi anti-pemerintah selama berbulan-bulan pasca-krisis ekonomi yang melanda Indonesia pada pertengahan 1997 akhirnya pecah, akibatnya sangat menciderai keberadaan masyarakat Tionghoa. Kasus kriminal yang ditujukan pada orang Tionghoa semakin mengkhawatirkan, bahkan sampai represif terhadap kehidupan orang Tionghoa yang berada di seluruh wilayah Indonesia. Akibatnya, ratusan ribu orang melarikan diri dari Indonesia. Selain itu, diperkirakan aset modal Cina yang berkisar miliaran dolar juga dicabut dari Indonesia (Sukma, 2009).

Kondisi serupa juga dialami masyarakat Tionghoa di Lasem, sanak saudara dari wilayah luar Rembang banyak yang mengungsi ke Lasem pada waktu itu. Beberapa identitas masyarakat Tionghoa kemudian cenderung disamarkan melalui pembauran langsung dengan budaya masyarakat Lasem.

"penyemuan identitas ada yang iya dan ada yang tidak, kalau aku dan kakakku emang ada semacam penyamaran, ya kami membaur aja sama lingkungan sekitar [...] lha kami gak suka dicino-cinokan, kami kan Indonesia bukan Cina, sudah biasa di Jawa, aku juga kalo dicina-cinake iki mangkel (sebel)" (Wawancara dengan CK, 2019) 
Pernyataan di atas menunjukkan bahwa masyarakat Tionghoa pada waktu itu berusaha untuk membangun identitas sosialnya kembali karena kerasnya tindakan diskriminatif. Hakikat yang sudah dibawa sejak lahir seperti identitas, atribut simbol, dan budayamereka tangguhkan. Kehidupan baru menjadi figur identitas orang Jawa mulai dicoba secara berkelanjutan hingga menyatu dengan status barunya sebagai masyarakat Lasem. Menurut Turner dan Allen (2007) kondisi demikian mendorong terjadinya amnesia auto hypnotised pada orang keturunan Tionghoa, yakni sebuah kondisi reaksi mental seseorang yang dengan sengaja melakukan tindakan untuk menghilangkan identitas dirinya sendiri.

"kalo kondisi masyarakat Tionghoa sendiri tidak bisa menilai itu semakin besar atau semakin menghilang, setahuku masih ada dari mereka yang melakukan tradisinya, tapi kalo ditanya kamu orang Tionghoa ya, mayoritas dari mereka bakal jawab aku orang Lasem karena aku lahir dan dibesarkan di Lasem dan aku juga memiliki darah keturunan, aku sendiri juga enggak begitu mikirin ras dan begituannya" (Wawancara dengan SA, 2019)

Ketakutan atas pengungkapan identitas diri orang Tionghoa berlangsung dalam kehidupan sosial sampai dengan data administratif kependudukan. Data hasil sensus Indonesia yang diambil pada tahun 2000, melaporkan hanya 1,8 juta orang Tionghoa peranakan yang mengungkapkan identitasnya secara terbuka. Angka ini tergolong rendah dan sangat mencerminkan keengganan kalangan orang keturunan Tionghoa untuk terdaftar resmi (Lindblad, 2007; Mackie, 2005).

"sekarang lihat, tahun setelah krismon, penurunan marga itu di Lasem orang Tionghoanya itu banyak menipis [...]kalo nama marga aku dan keluargaku ada, tapi kan di Lasem ini sekarang banyak yang manggil nama Jawa atau Indonesia, dan setahuku nama marga gak dicatat di akta kelahiran, jadi jarang digunakan sekarang, manggil aja pakek nama biasa" (Wawancara dengan CK, 2019)

Masyarakat Tionghoa Lasem turut membenarkan tentang keengganan anggota keluarga mereka yang dulu tidak mendaftarkan diri secara administratif. Alasannya dapat diklasifikasikan ke dalam beberapa faktor; pertama, absennya negara dalam melindungi hak-hak orang Tionghoa sebagai kelompok minoritas. Kedua, melemahnya identitas masyarakat Tionghoa karena peristiwa tahun 1998. Keti$g a$, keberhasilan penyerapan unsur-unsur nilai melalui hibridasi dan mimikri.

\section{Identitas Hibrid menjadi Cina-Jawa}

Masyarakat keturunan Tionghoa yang hidup di Lasem setidaknya telah mengalami hibridasi dan mimikri identitasnya karena kondisi dan situasi yang mendesaknya untuk berubah. Perpaduan subjek budaya melalui proses silang nilai (hibridasi) dapat di telisik sejak Orde Baru, yakni melalui kebijakan pemerintah tentang asimilasi. Nilai-nilai yang di hibridasi masyarakat Tionghoa di Lasem lebih banyak terjadi pada dimensi rasial, linguistik, keagamaan, dan budaya. Prosesnya dilakukan dengan konsep mimikri, seperti amalgamasi, peminjaman simbol budaya, peniruan nilai-nilai Jawa, dan penyamaran identitas menjadi penduduk lokal.

Cara-cara yang dilakukan oleh Tionghoa di Lasem dinilai efektif berhasil, tetapi masih memberikan dampak negatif yang menyakitkan untuk masyarakat Tionghoa. Seperti yang ditunjukkan oleh fakta bahwa kebanyakan dari individu tidak berbicara bahasa Mandarin sama sekali; beberapa hanya bisa berbicara, tetapi tidak bisa membaca dan menulis (Tan dan Dahana, 1997). Pembauran yang awalnya dipaksakan, setidaknya mendorong perubahan identitas dengan menjalani kehidupan barunya 
sebagai masyarakat Tionghoa-Lasem.

"Pernikahan Jawa-Cina kalau di keluargaku ada, tapi kebanyakan budaya $\mathrm{Ci}$ na-nya menghilang, lebih njawani malah (terkesan menjawai), dan bahasa setiap hari ya bahasa Jawa, keluargaku sekarang yang masih hidup gak bisa bahasa Cina sama sekali, ehh ada yang bisa bahasa Cina, itu kelompok yang di Klenteng, tapi aku sudah gak pernah ikut acara gitu-gitu itu" (Wawancara dengan CK, 2019)

Melalui pembelajaran budaya sekitar Lasem, masyarakat keturunan mulai membiasakan diri dengan identitasnya sebagai Jawa yang berorientasi ke-Indonesia-an. Proses mimikri yang dilakukan sebagai strategi bertahan menghadapi kelompok mayoritas yang berkuasa masih dilakukan hingga sekarang. Seluruh dimensi kehidupan bermasyarakat terus dihibridasi dan dimimikri sesuai dengan perubahan sosial yang semakin kompleks.

Fenomena hibridasi dan mimikri masyarakat Tionghoa Lasem akhirnya membentuk identitas baru berupa Cina-Jawa atau lebih dikenal dengan bumi putra dan wong Lasem. Reidentifikasi identitas hibrid ini memungkinkan terjadi karena dipengaruhi oleh perubahan sosial, misalnya perubahan sistem sosial-politik Indonesia secara besar-besaran yang menciptakan ketakutan sehingga mendorong individu untuk mereproduksi identitasnya kembali dalam masyarakat Lasem. Budaya baru ini menunjukkan pengakuan terhadap proses transformatif masyarakat Tionghoa menjadi identitas Tionghoa-Indonesia; bahkan menjadi Tionghoa-Jawa yang kreatif, adaptif, dan hibrid. Dalam hal ini, hibridasi tidak hanya bergantung pada gagasan asimilatif belaka, melainkan turut membentuk identitas baru yang lebih esensial (Ang, 2001).

“zaman dulu buyut, kakek, dan orang tu- aku, plus tante om-ku dipanggil nama Cinanya, tapi kalau sekarang, sudah hampir enggak, sudah pada pakai nama Indonesia [...] biasanya agama sih juga yang berubah, beberapa saudaraku mu'alaf, kalau adat istiadat ada, nama marga tetap juga kok" (Wawancara dengan CK, 2019)

Kutipan wawancara di atas menjelaskan bagaimana masyarakat Tionghoa Lasem saat ini. Masyarakat Tionghoa masih banyak yang tinggal dan menetap di Lasem, meskipun dengan identitas barunya yang cenderung berbau lokal. Meskipun demikian, dalam beberapa kasus, masyarakat keturunan Tionghoa di Lasem masih tetap terpinggirkan karena dianggap sebagai orang yang asing. Contoh paling nyata terjadi dalam persaingan industri batik tulis Lasem yang timpang akan kepentingan masyarakat Jawa. Akibatnya, akses produksi sampai distribusi batik tulis banyak dijalankan oleh pemilik modal besar; mayoritas pengusaha Jawa.

"masih ada mungkin yang membedakan, tapi kita sama orang Jawa, juga gak boleh berbeda sikap, kita sama-sama orang Lasem, makanya kita harus bersatu, gak ada Cina, gak ada Jawa disini, semuanya sama, saling rukun, menghormati" (Wawancara dengan PW, 2019)

Hal ini menjadi relevan dengan keberadaan identitas Tionghoa-Jawa versi Lasem yang dibentuk oleh lokalisasi identitasnya. Akan tetapi, keturunan Tionghoa yang hidup di Lasem sejatinya belum dapat diterima sebagai orang Indonesia sepenuhnya dan tidak pernah bisa melepaskan identitasnya sebagai pendatang. Mereka secara habitus kultural menyadari kejawaannya, tetapi sebagai subjek otentik tidak akan tercapai karena konseptualisasi hibridasi melibatkan berbagai aliran budaya yang memungkinkan bergantung pada kemauan kelompok dominan (Hoon, 2006b).

\section{Simpulan}


Perubahan sosial pada masyarakat Tionghoa didorong oleh fenomena besar yang terjadi pada dua periode. Periode pertama terjadi ketika masa Orde Baru yang dipraktikkan melalui kebijakan asimilasi. Pemberlakuan kebijakan di masa pemerintahan Soeharto ini menjadi titik awal perubahan budaya dan identitas. Keturunan Tionghoa banyak yang dipaksa untuk menghilangkan tradisi yang dibawa oleh nenek moyangnya dengan cara represif. Periode kedua terjadi selepas reformasi pemerintahan Orde Baru di tahun 1998. Masyarakat keturunan Tionghoa yang sebelumnya terlabeli sebagai kelompok periferal mencoba bangkit melalui pendekatan persuasif yaitu berbaur dengan kehidupan masyarakat setempat.

Dua periode besar yang terjadi di Indonesia memang menyebabkan perubahan sosial masyarakat Tionghoa di Lasem. Hal tersebut mendorong keturunan Tionghoa di Lasem melakukan proses hibridasi dan mimikri dengan tujuan preventif menghadapi kemungkinan konflik sosial. Melalui hibridasi, masyarakat Tionghoa melakukan strategi dengan cara akulturasi dan asimilasi identitas, budaya, bahasa, dan rasial untuk menghadapi dominasi kelompok mayoritas. Selain itu, mimikri dilakukan oleh masyarakat Tionghoa dengan meminjam, meniru, dan menyelaraskan nilai subjektif dengan nilai kelompok dominan; masyarakat Jawa. Prosesi ini bukan hanya peniruan belaka, tetapi bentuk perlawanan subversif melalui kamuflase diri dengan mengurangi perbedaan antara minoritas dengan mayoritas untuk membela diri atau bertahan hidup.

Korelasi antara perubahan sosial dengan hibridasi dan mimikri yang terjadi di Lasem akhirnya menciptakan kebaharuan nilai budaya Cina-Jawa dan identitas sosial; wong Lasem. Baik masyarakat Tionghoa ataupun Jawa — tidak terlalu signifikansaling mencabut tradisi dan identitas tradisionalnya untuk saling beradaptasi dalam segi identitas, perilaku, dan budaya. Dorongan relasi sosial antara masyarakat lokal Lasem dengan keturunan masyarakat Tionghoa yang terjalin sejak lama semakin memudahkan adanya transisi dan pengakuan identitasnya yang baru. Ketergan- tungan sosial untuk saling melengkapi menambah peleburan segregasi perbedaan antar-golongan. Masyarakat Tionghoa Lasem tampaknya berhasil melakukan proses asimilasi budaya dengan baik sehingga konflik kepentingan berbasis golongan seperti tahun 1998 tidak pernah terjadi di Lasem.

\section{Daftar Pustaka}

Ang, I. (2001). On Not Speaking Chinese: Living Between Asia and the West. London: Routledge.

Anthias, F. (2001). New Hybridities, Old Concepts: The Limits of "Culture." Ethnic and Racial Studies, 24(4), 619-641.

Atabik, A. (2016). Percampuran Budaya Jawa dan Cina: Harmoni dan Toleransi Beragama Masyarakat Lasem. Sabda: Jurnal Kajian Kebudayaan, 11(1), 1.

Bhabha, H. K. (1994). The Location of Culture. London: Routledge.

Carnegie, P. J. (2019). National Imaginary, Ethnic Plurality, and State Formation in Indonesia BT - The Palgrave Handbook of Ethnicity (S. Ratuva, ed.).

Coppel, C. (2002). Studying Ethnic Chinese in Indonesia. Singapore: Singapore Society of Asian Studies.

Coppel, C. A. (1994). Tionghoa Indonesia Dalam Krisis. Jakarta: Pustaka Sinar Harapan.

Darmawan, D. (2014). Identitas Hibrid Orang Cina. Yogyakarta: Gading Publishing.

Foulcher, K., dan Day, T. (2008). Sastra Indonesia Modern Kritik Postkolonial. Jakarta: Yayasan Pustaka Obor Indonesia.

Heryanto, A. (2015). Identitas dan Kenikmatan: Politik Budaya Layar Indonesia. Jakarta: Kepustakaan Populer Gramedia.

Hoon, C.-Y. (2006a). A Hundred Flowers Bloom: The Re-emergence of The Chinese Press in Post Suharto Indonesia. In Media and Chinese Diaspora: Community, Communication and Commerce. London: Routledge.

Hoon, C.-Y. (2006b). Assimilation, Multiculturalism, Hybridity: The Dilemmas of The Ethnic Chinese in Post-Suharto Indonesia. Asian Ethnicity, 7(2), 149-166.

Komnas Perempuan. (2012). Napak Reformasi: Tragedi Mei 1998. Jakarta.

Johnson, D. P. (1986). Teori Sosiologi Klasik dan Modern. Jakarta: Kepustakaan Populer Gramedia.

Lindblad, J. T. (2007). Indonesia and China 
Today: New Challenges with a Long History. Journal of Developing Societies, 23(3), 369392.

Mackie, J.(2005). How many Chinese Indonesians? Bulletin of Indonesian Economic Studies, 41(1), 97-101.

Parsons, T. (1951). The Social System. New York: Free Press.

Poerwanto, H. (1976). The Problem of Chinese Assimilation and Integration In Indonesia. Philippine Sociological Review, 24(1/4), 51-55.

Siegel, J. T. (1998). Early Thoughts on the Violence of May 13 and 14, 1998 in Jakarta. Indonesia, 10(66), 75-108.

Sukma, R. (2009). Indonesia-China Relations: The Politics of Reengagement. In S. Tang, M. Li, dan A. Acharya (Eds.), Living with China: Regional States and China through Crises and Turning Points (pp. 89-106).

Suryadinata, L. (1978). The Chinese Minority in Indonesia: Seven Papers. Singapore: Chopmen Enterprises.

Suryadinata, L. (2002). Negara dan Etnis Tionghoa: Kasus Indonesia. Jakarta: LP3ES.

Tan, M. G., dan Dahana, A. (1997). The Ethnic Chinese in Indonesia: Issues of Identity. In L. Suryadinata (Ed.), Ethnic Chinese as Southeast Asians (pp. 33-71).

Turner, S., dan Allen, P. (2007). Chinese Indonesians in A Rapidly Changing Nation: Pressures of Ethnicity and Identity. Asia Pacific Viewpoint, 48(1), 112-127.

Tzû-jan, L., Hsing, K., dan Hsi-Chih, C. (2016). The Structure of the Indonesian Chinese Society. Southeast Asian Journal of Social Science, 9(1/2), 130-132.

Wibowo, I. (2001). Exit, Voice, and Loyalty: Indonesian Chinese after the Fall of Soeharto. Sojourn: Journal of Social Issues in Southeast Asia, 16(1), 125-146. 